\title{
Synthesis, characterization, and efficacy of antituberculosis isoniazid zinc aluminum-layered double hydroxide based nanocomposites
}

This article was published in the following Dove Press journal:

International Journal of Nanomedicine

I5 July 2016

Number of times this article has been viewed

\author{
Bullo Saifullah' \\ Mohamed Ezzat El \\ Zowalaty ${ }^{2,3}$ \\ Palanisamy Arulselvan ${ }^{3}$ \\ Sharida Fakurazi ${ }^{3,4}$ \\ Thomas J Webster ${ }^{5-7}$ \\ Benjamin Mahler Geilich ${ }^{5,6}$ \\ Mohd Zobir Hussein' \\ 'Materials Synthesis and \\ Characterization Laboratory, Institute \\ of Advanced Technology, (ITMA), \\ Universiti Putra Malaysia, Serdang, \\ Selangor, Malaysia; ${ }^{2}$ School of Health \\ Sciences, University of KwaZulu- \\ Natal, Westville Campus, Durban, \\ South Africa; ${ }^{3}$ Laboratory of Vaccines \\ and Immunotherapeutics, Institute of \\ Bioscience, ${ }^{4}$ Department of Human \\ Anatomy, Faculty of Medicine and \\ Health Science, Universiti Putra \\ Malaysia, Serdang, Selangor, Malaysia; \\ ${ }^{5}$ Department of Chemical Engineering, \\ ${ }^{6}$ Department of Bioengineering, \\ Northeastern University, Boston, \\ MA, USA $;{ }^{7}$ Center of Excellence \\ for Advanced Materials Research, \\ King Abdulaziz University, Jeddah, \\ Saudi Arabia
}

Correspondence: Mohd Zobir Hussein Materials Synthesis and Characterization Laboratory, Institute of Advanced Technology, (ITMA), Universiti Putra Malaysia, PO Box 43400 UPM, Serdang, Selangor 43400, Malaysia

Tel +60389466801

Fax +60389435380

Email mzobir@upm.edu.my

\begin{abstract}
The chemotherapy for tuberculosis (TB) is complicated by its long-term treatment, its frequent drug dosing, and the adverse effects of anti-TB drugs. In this study, we have developed two nanocomposites (A and B) by intercalating the anti-TB drug isoniazid (INH) into Zn/Al-layered double hydroxides. The average size of the nanocomposites was found to be $\sim 164 \mathrm{~nm}$. The efficacy of the Zn/Al-layered double hydroxides intercalated INH against Mycobacterium tuberculosis was increased by approximately three times more than free INH. The nanocomposites were also found to be active against Gram-positive and -negative bacteria. Compared to the free INH, the nanodelivery formulation was determined to be three times more biocompatible with human normal lung fibroblast MRC-5 cells and 3 T3 fibroblast cells at a very high concentration of $50 \mu \mathrm{g} / \mathrm{mL}$ for up to 72 hours. The in vitro release of INH from the $\mathrm{Zn}$ /Al-layered double hydroxides was found to be sustained in human body-simulated buffer solutions of $\mathrm{pH} 4.8$ and 7.4. This research is a step forward in making the TB chemotherapy patient friendly.
\end{abstract}

Keywords: tuberculosis, Zn/Al-LDHs, drug delivery, biomaterial, antimicrobial, activity, sustained release formulation, nanomedicine

\section{Introduction}

Human pulmonary tuberculosis (TB) is a chronic infectious disease of global public health concern. The disease is caused by Mycobacterium tuberculosis and has been lethal to humans for centuries. Chemotherapy of TB represents a challenge and is complicated by multidrug therapy, frequent dosing, side effects of anti-TB drugs, an extended treatment duration, and multiple regimens. ${ }^{1}$ These complications result in noncompliance to the TB chemotherapy among patients. Patient noncompliance is the most common cause of treatment failure and the emergence of multidrug-resistant TB. ${ }^{2,3}$ Multidrug-resistant $\mathrm{TB}$ is one of the worst forms of TB; it is treated with second-line anti-TB drugs that have more adverse effects and treatment lasts for up to 2 years. ${ }^{4,5}$ According to the latest global TB report (October 22, 2014), the estimated number of new cases of TB in the year 2013 was 9 million, and there were 1.5 million humans who died from TB. ${ }^{6}$

Isonicotinic acid hydrazine, commonly known as isoniazid (INH), is the most powerful first-line anti-TB drug that is also used in the treatment of leprosy. ${ }^{7,8}$ TB patients must take $300 \mathrm{mg}$ of INH daily for 6 months along with other first-line anti-TB drugs. ${ }^{9}$ INH causes severe side effects, such as hyperacute liver failure, hydralazine hypotension, jaundice, and hepatotoxicity. ${ }^{9-12}$ Although INH is a very powerful anti-TB drug, because of these serious side effects, the INH dose is limited to certain concentrations. The emergence of the resistance of $M$. tuberculosis against INH is a multifactorial 
phenomenon, including subtherapeutic doses. A drug delivery system that can first deliver the anti-TB drugs at high concentrations followed by a sustained release would be able to maintain the minimum inhibitory concentration (MIC) required to inhibit the bacterial growth over longer periods of time. ${ }^{13}$ Furthermore, the targeted and sustained delivery would reduce dosing frequency and minimize side effects. ${ }^{14,15}$

M. tuberculosis is an obligate intracellular pathogen, and the almost exclusive cellular host of M. tuberculosis is the alveolar macrophage where the microorganism lives and multiplies within the macrophage that have the tendency to take up nanoparticles in comparison to the other host cells. ${ }^{16-20}$ In this context, biocompatible nanodelivery systems have tremendous potential to target the M. tuberculosis bacteria inside the phagocytes, and these nanodelivery systems also protect the drug from physiochemical degradation in the body. Biocompatible nanodelivery systems could enhance the therapeutic efficacy of the drug and would ultimately improve patients' compliance to the chemotherapy of TB. ${ }^{14,21,22}$

In recent years, inorganic nanolayers, namely, layered double hydroxides (LDHs), have emerged as biocompatible drug delivery systems with excellent characteristics, such as ease of preparation, tendency of loading various pharmaceutical drugs, release of the drugs in a sustained manner, biocompatibility, and biodegradability. ${ }^{15,22-24}$ Excellent reviews have been written by Saifullah and Hussein ${ }^{25}$ and Rives et $\mathrm{al}^{26,27}$ describing in detail the drug delivery applications of LDHs.

In the present work, we describe the development of an anti-TB nanodelivery system by intercalating INH into $\mathrm{Zn} / \mathrm{Al}$-LDHs prepared by the coprecipitation and ion exchange methods. The sustained release of INH from the galleries of $\mathrm{Zn} / \mathrm{Al}$-LDHs was determined in physiologically simulated phosphate-buffered saline (PBS) solutions at $\mathrm{pH}$ values of 4.8 (intracellular lysosomal $\mathrm{pH}$ ) and 7.4 (blood $\mathrm{pH}$ ). In addition, the antimicrobial activities of the formulations were investigated against $M$. tuberculosis and other microorganisms. The cytotoxicity of the INH nanocomposites was also determined against human lung cells (MRC-5) and 3T3 mouse fibroblast cells.

\section{Materials and methods}

Institute of Bioscience Ethics Committee and Institutional Review Board approval are not applicable for this experiment because human or animal subjects were not used in the experiments.

\section{Chemicals}

Analytical-grade chemicals were used without any further purification. INH was $99 \%$ pure, and zinc nitrate hexahydrate and aluminum nitrate nonahydrate were purchased from
Sigma-Aldrich (St Louis, MO, USA). Dimethyl sulfoxide was purchased from Ajax Finechem (Sydney, Australia) and deionized water was used in all of the experimental work.

\section{Cell culture}

Human lung fibroblast MRC-5 (ATCC ${ }^{\circledR}$ CCL-171 ${ }^{\mathrm{TM}}$ ) and 3T3-Swiss albino (ATCC ${ }^{\circledR}$ CCL-92 ${ }^{\mathrm{TM}}$ ) cells were purchased from American Type Culture Collection (ATCC; Manassas, VA, USA), and the cells were cultured in Dulbecco's Modified Eagle's Medium and Roswell Park Memorial Institute (RPMI) 1640 media containing 10\% fetal bovine serum. The growth media contained 100 units/mL penicillin and $50 \mu \mathrm{g} / \mathrm{mL}$ streptomycin, respectively. The cells were maintained at $37^{\circ} \mathrm{C}$ in a humidified atmosphere in the presence of $5 \% \mathrm{CO}_{2}$.

\section{Preparation of INH-Zn/AI-LDH using coprecipitation}

A previously optimized method with a slight modification was used for the preparation of the nanocomposite. ${ }^{28}$ In brief, a solution of $\mathrm{Zn}^{2+} / \mathrm{Al}^{3+}$ nitrate salts at a ratio of 2:1 was prepared in $50 \mathrm{~mL}$ of $\mathrm{H}_{2} \mathrm{O}$ and stirred for 15 minutes under continuous nitrogen flux. Then, $50 \mathrm{~mL}$ of a $1 \mathrm{~mol} / \mathrm{L}$ solution of INH was added to the salt solution and stirred for an additional 20 minutes, and the $\mathrm{pH}$ was raised to 7.5 by the slow addition of $1 \mathrm{~mol} / \mathrm{L}$ sodium hydroxide. Then, the sample was subjected to oil-bath shaking at $70^{\circ} \mathrm{C}$ for 2 days, centrifuged, and washed thoroughly with deionized water. The sample was dried in an oven at $70^{\circ} \mathrm{C}$ for 48 hours and ground into a fine powder and then subjected to further characterization. The sample prepared by the coprecipitation method is referred to as nanocomposite- $\mathrm{A}$ in the rest of the manuscript.

\section{Preparation of INH-Zn/AI-LDH using ion exchange}

The preparation by ion exchange was performed using a previously optimized method with slight modification. ${ }^{28} \mathrm{In}$ short: a salt solution of $\mathrm{Zn}^{+2} / \mathrm{Al}^{+3}$ at a ratio of $4: 1$ was prepared in $25 \mathrm{~mL}$ water and stirred for 15 minutes. Then, this salt solution was added dropwise to another $25 \mathrm{~mL}$ of $\mathrm{H}_{2} \mathrm{O}$, and a pH of 7-7.5 was maintained by the simultaneous addition of $0.5 \mathrm{M}$ sodium hydroxide. Next, $100 \mathrm{~mL}$ of a $1 \mathrm{M}$ INH solution was added dropwise to the freshly prepared LDH; the experiment was performed under a continuous nitrogen flux. Then, the sample was stirred continuously for 2 days at room temperature, sealed with parafilm, and then subjected to oil-bath agitation for 4 days at $70^{\circ} \mathrm{C}$. Then, the sample was centrifuged and washed thoroughly with deionized water. Subsequently, the sample was dried at $70^{\circ} \mathrm{C}$ for 
48 hours. After drying, the sample was ground into a powder and processed further for the characterization studies. This sample prepared by the ion exchange method is termed as nanocomposite-B in rest of the manuscript.

\section{Characterization of INH nanocomposites}

A Shimadzu XRD-6000 diffractometer(Shimadzu Corporation, Tokyo, Japan), was used for the X-ray diffraction (XRD) studies. $\mathrm{CuK}_{\alpha}$ radiation at $30 \mathrm{kV}$ and $30 \mathrm{~mA}$ was used to record the powder-XRD patterns in the $2 \theta$ range of $2^{\circ}-60^{\circ}$. Fourier transform infrared (FTIR) spectra of the materials were recorded over the range of $400-4,000 \mathrm{~cm}^{-1}$ on a Perkin-Elmer 100 series spectrophotometer by a direct sample method. For the analysis of carbon, hydrogen, and nitrogen, a LECO model CHNS-932 instrument (St Joseph, MI, USA) was used. For the thermogravimetric and differential thermogravimetric analyses, a Mettler Toledo instrument (Greifensee, Switzerland) was used. For the thermal analysis, samples were subjected to heating from $25^{\circ} \mathrm{C}$ to $1,000^{\circ} \mathrm{C}$ with an increase at a rate of $10^{\circ} \mathrm{C} / \mathrm{min}$. The analysis was performed under nitrogen purging. The morphology of the sample surface was studied by a scanning electron microscope, JOEL JSM-6400 (JEOL, Tokyo, Japan). A Shimadzu UV-1650-PC UV/Vis spectrophotometer was used for the optical properties, UV/ Vis spectra, and controlled-release studies under atmospheric conditions. Dynamic light scattering was applied using a Zeta sizer nanoseries - NANO-S Malvern instrument - for the determination of nanocomposite particle size.

\section{Quantification of INH using HPLC analysis}

For the loading quantification of INH in Zn/Al-LDHs, a Sykam high performance liquid chromatography (HPLC) system (SYKAM GmbH, Eresing, Germany) was used with the auto injector Sykam 5300, a Sykam S3250 UV/Vis detector, and the Sykam quaternary pump system 5300 made in Germany, with a Zorbax Rx-Sil column of 4.6×150 mm, with $5 \mu \mathrm{m}$ particle size (Agilent Technologies, Santa Clara, CA, USA). For the quantification of INH, a previously reported method was used with slight modification. ${ }^{29}$ In brief, the analysis was performed at $30^{\circ} \mathrm{C}$ with a $1 \mathrm{~mL} / \mathrm{min}$ flow rate, and the total run time was 10 minutes for each run, and the retention time for INH was 2.27 minutes. The mobile phase was composed of acetonitrile (A) and $15 \mathrm{mmol} / \mathrm{L}$ potassium dihydrogen phosphate buffer at a $\mathrm{pH}$ adjusted to $4.0 \pm 0.1$ with o-phosphoric acid (B). The ratio of the mobile phase A:B was 89:11 and the wavelength $235 \mathrm{~nm}$ was selected for the UV detector. The standard solutions of various INH concentrations, that is, $0,30,60$, and
90 ppm, were prepared in $50 \mathrm{~mL}$ with $45 \mathrm{~mL}$ mobile phases plus $5 \mathrm{~mL}$ of $\mathrm{HCl}$. In the same way, $10 \mathrm{mg}$ of each nanocomposite was dissolved in $5 \mathrm{~mL}$ of $\mathrm{HCl}$ and $45 \mathrm{~mL}$ of the mobile phase. The samples, standards, and mobile phase were filtered with $0.20 \mu \mathrm{m}$ (pore size) filters. For the standards, the correlation coefficient $R^{2}$ was determined to be 0.9971 .

\section{Sustained-release test}

Human body-simulated 0.1 M PBS solutions of $\mathrm{pH}$ values of 7.4 (blood $\mathrm{pH}$ ) and 4.8 (intracellular lysosomal $\mathrm{pH}$ ) were used to study the sustained release of INH from the inorganic galleries of $\mathrm{Zn} / \mathrm{Al}$-LDHs. Approximately $0.4 \mathrm{mg}$ each of nanocomposites- $\mathrm{A}$ and $\mathrm{B}$ were placed into $3.5 \mathrm{~mL}$ of $\mathrm{pH} 7.4$ and 4.8 PBS solutions, and the absorbance at the wavelength $\lambda_{\max }=271 \mathrm{~nm}$ was selected on the UV/Vis spectrophotometer to study the release of INH from the nanocomposites.

\section{Antimicrobial susceptibility tests Bactec MGIT 960 system}

The drug susceptibility testing (DST) of INH-Zn/Al-LDH nanocomposites using the BBL nonradiometric fluorescencebased method of MGIT 960 against M. tuberculosis (ATCC ${ }^{\circledR}$ $25618^{\mathrm{TM}}$ ) was used, and the MICs of the nanocomposites were determined. The Mycobacteria Growth Indicator Tube (MGIT) with BACTEC MGIT 960 growth supplement for DST was used in an MGIT 960 instrument (Becton Dickinson Diagnostic Systems, Sparks, MD, USA) as described previously. ${ }^{30,31}$ The standard protocol for DST in MGIT 960 was strictly followed as recommended for primary drugs. The culture suspensions for inoculation were well dispersed with no large clumps to avoid false-resistant results. After thorough mixing and homogenization of the culture suspensions, the tubes were allowed to rest for at least 15 minutes, and the supernatant was used to inoculate the drug-containing media and the control according to the manufacturer's instructions for DST of first-line drugs. All inoculated drug-containing MGIT 960 tubes were placed in the DST set carrier and entered into the MGIT 960 instrument as "unknown drugs" using the DST entry feature. For the DST set containing "unknown drugs", the instrument flagged the DST set "complete" when the growth control reached a growth unit (GU) value of 400 . At this point, the GU values of the drug-containing tubes were retrieved from the instrument by printing a DST set report, and the results were interpreted manually. If the GU of the drug-containing tube was $>100$ when the GU of the growth control was 400, the results were defined as resistant. If the GU values of the drug-containing tubes were equal to or $<100$, the results were considered susceptible. Experiments were repeated with various concentrations of 
the INH-Zn/Al-LDH nanocomposite suspensions until the MIC was determined.

\section{Growth-inhibition kinetics}

To quantitatively evaluate the antimicrobial effect of the as-synthesized INH nanocomposites-A and B on the growth kinetics of various microorganisms, the plate colony count method was employed. Prior to treatment with the nanocomposites, the bacterial cultures of Staphylococcus aureus (ATCC ${ }^{\circledR} 43300^{\mathrm{TM}}$ ), Pseudomonas aeruginosa $\left(\mathrm{ATCC}^{\circledR} 27853^{\mathrm{TM}}\right)$, Escherichia coli $\left(\mathrm{ATCC}^{\circledR} 25922^{\mathrm{TM}}\right)$, and Candida albicans (ATCC ${ }^{\circledR} 20408^{\mathrm{TM}}$ ) were obtained from ATCC and hydrated and streaked for isolation on a tryptic soy agar plate. Following growth, a single isolated colony was selected and used to inoculate $3 \mathrm{~mL}$ of $20 \%$ tryptic soy broth medium. The bacterial culture was grown on a shaking incubator set at $200 \mathrm{rpm}$ for 18 hours at $37^{\circ} \mathrm{C}$. The resulting bacterial suspension was then adjusted to have an $\mathrm{OD}_{570}$ of 0.52 , corresponding to a bacterial density of $10^{9}$ colony forming units (CFU) per mL. Then, the bacterial suspension was serially diluted over a 4-log range to a bacterial density of $10^{4} \mathrm{CFU} / \mathrm{mL}$ using $20 \%$ tryptic soy broth. A volume of $1 \mathrm{~mL}$ of the bacterial suspension was treated with the nanocomposite suspension at concentrations of 10 and $20 \mathrm{mg} / \mathrm{mL}$ in separate wells of a 24-well plate and allowed to incubate for 1 hour at $37^{\circ} \mathrm{C}$. The number of CFUs after treatment was determined using the plate-counting method following plating onto tryptic soy agar plates. The experiment was repeated in triplicate. The percentage of inhibition of each nanocomposite against each microorganism was calculated according to the following equation:

$$
\text { Inhibition rate }=1-\frac{\mathrm{CFU}_{\text {treated }}}{\mathrm{OD}_{\text {control }}} \times 100
$$

The efficiency of the nanocomposites to inhibit the growth of the microorganisms was determined by differences in the equivalent number of the CFU before and after treatment as the percentage of microbes that were inhibited by the nanocomposites; this was calculated from the previous equation.

\section{In vitro assay for cell viability}

To determine and compare the cytotoxicity of the synthesized nanocomposites, the MTT cytotoxicity experiment was performed according to a previously optimized method. ${ }^{22,32}$ Briefly, 3T3 mouse fibroblast and human lung fibroblast MRC-5 cells were cultured in Dulbecco's Modified Eagle's
Medium and RPMI 1640 medium containing 10\% fetal bovine serum. The growth media contained 100 units $/ \mathrm{mL}$ penicillin and $50 \mu \mathrm{g} / \mathrm{mL}$ streptomycin, respectively, and the cells were maintained at $37^{\circ} \mathrm{C}$ in a humidified atmosphere of $5 \% \mathrm{CO}_{2}$. The cells were seeded onto 96-well culture plates at $1 \times 10^{4}$ cells per well, and after a 24-hour seeding, the cells were incubated with a medium $(100 \mu \mathrm{L})$ containing dispersed nanocomposites at various concentrations from 0.781 to $50 \mu \mathrm{g} / \mathrm{mL}$ at the specific time points, 24, 48, and 72 hours. Plates treated with the medium without the dispersed nanocomposites were run in parallel and used as control plates. Following treatment, the amount of formazan crystals formed was measured after 4 hours of MTT solution in PBS, and the absorbance values were measured at $570 \mathrm{~nm}$ by an enzyme-linked immunosorbent assay (ELISA) plate reader. Cytotoxicity experiments were performed in triplicate, and the cytotoxicity results were calculated according to the previously described method. The results are presented as the mean \pm standard deviation.

\section{Results and discussion Powder XRD}

Figure 1A-C shows the XRD patterns of the nanocomposites prepared by coprecipitation (nanocomposite-A) and ion exchange (nanocomposite-B) and the naked drug $\mathrm{INH}$, respectively. The basal spacing of the $\mathrm{Zn} / \mathrm{Al}$-LDHs with nitrate ions between the galleries was $8.9 \AA .^{28}$ The XRD results of the nanocomposites show that the basal spacing increased to 12.01 and $11.53 \AA$ for nanocomposites- $\mathrm{A}$ and $\mathrm{B}$, respectively, and these peaks are the first reflection (ie, (003) for both nanocomposites). This increased basal spacing from 8.9 to $12.01 \AA$ and $11.53 \AA$ indicated a

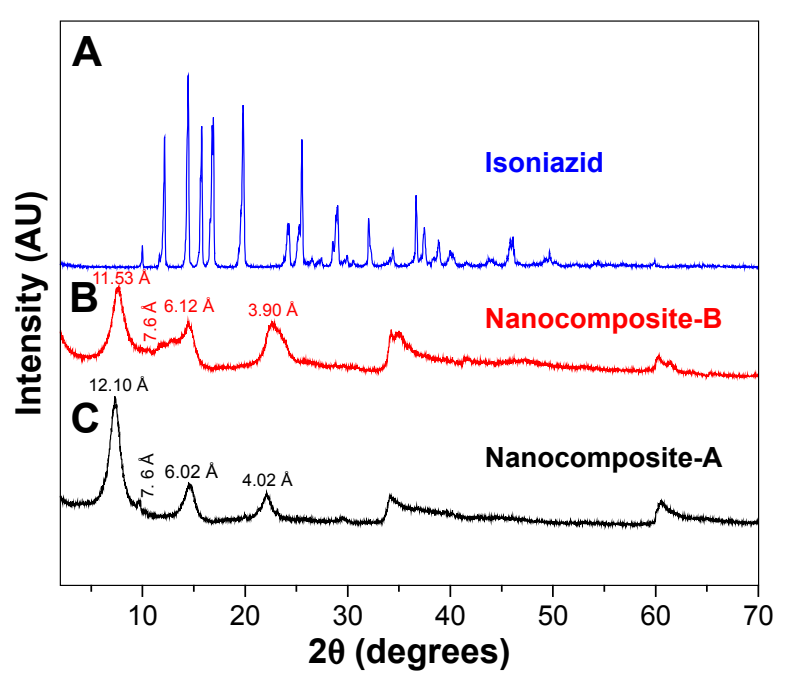

Figure I (A-C) XRD pattern for the nanocomposites-A and -B and isoniazid. Abbreviation: $X R D, X$-ray diffraction. 
successful intercalation of INH between the interlayer galleries of the $\mathrm{Zn} / \mathrm{Al}-\mathrm{LDH}$. Furthermore, the XRD results show that the other reflections (006) and (009) are also present for both nanocomposites-A and $\mathrm{B}$, which indicate the high crystallinity of the samples. A very-low-intensity peak with a basal spacing of $\sim 7.6 \AA$ (Figure 1A) and (Figure 1B) indicates the presence of carbonate intercalation, which is a common phenomenon in LDHs.

\section{Spatial orientation of INH between the interlayer galleries of the $\mathrm{Zn} / \mathrm{Al}-\mathrm{LDH}$}

The 3D molecular size for INH was determined using Chem Office Software 2008 (Cambridge, MA, USA). The vertical and horizontal axes plus the thickness were calculated and found to be 10.5, 7.2, and 3.1 $\AA$, respectively (Figure 2A). The spatial orientation of the intercalated molecule was determined by subtracting the layer thickness of the LDHs (ie, $4.8 \AA)^{28}$ from the average basal spacing for both of the nanocomposites. The average basal spacing for both of the nanocomposites were $\sim 12.0 \AA$, and by subtracting the thickness of the LDHs (ie, $4.8 \AA$ from $12.0 \AA$ ), the remaining value becomes $7.2 \AA$. Keeping in mind the electrostatic interaction between INH and Zn/Al-LDHs, the most probable orientation of INH between the interlayer gallery can be vertically oriented with tilted angle, as shown in Figure 2B.

A

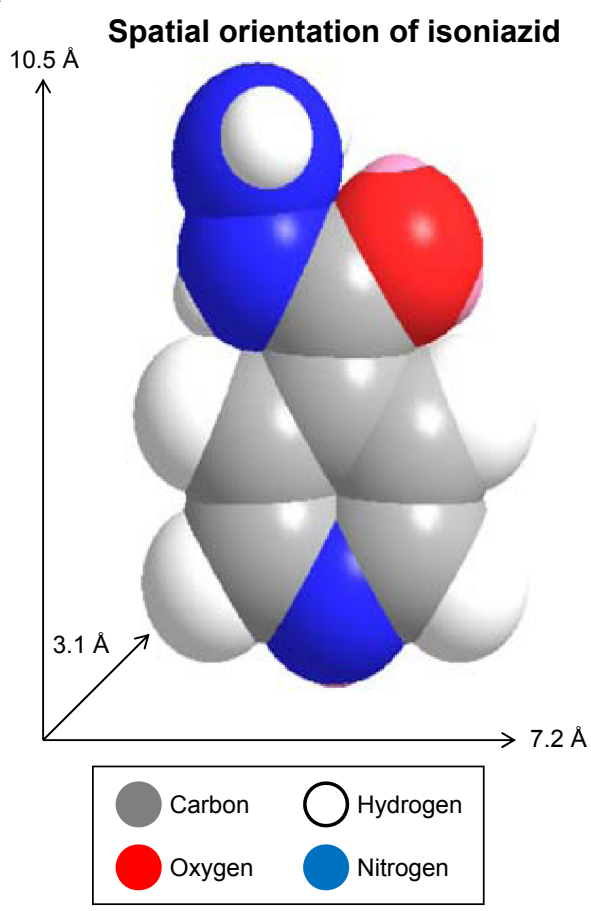

\section{FTIR spectroscopy}

Figure $3 \mathrm{~A}-\mathrm{C}$ shows the infrared spectra of the nanocomposite-A (Figure 3A) and nanocomposite-B (Figure $3 \mathrm{~B}$ ) and INH (Figure 3C). The FTIR spectrum of the pure drug INH (Figure 3C) shows several of the characteristic functionalgroup bands. The main bands are the carbonyl $\mathrm{C}=\mathrm{O}$; amino group $\mathrm{NH}_{2}$; and $\mathrm{N}-\mathrm{N}$ single bond, $\mathrm{C}=\mathrm{C}$ double bonds, and a $\mathrm{C}-\mathrm{H}$ bond of the aromatic ring. The wave numbers of these bands are given in Table 1. The LDHs have characteristic infrared bands from 3,000 to $3,400 \mathrm{~cm}^{-1}$ due to the $\mathrm{OH}$ vibration and also from the interlayer $\mathrm{H}_{2} \mathrm{O}$. The nanocomposites- $\mathrm{A}$ and $\mathrm{B}$ contain almost all of the bands of the pure drug and the LDHs, with a slight shift in the wave numbers of certain peaks due to the drug interaction with the inorganic hosts. Such a shift can be observed for the carbonyl band, which is shifted to 1,600 from $1,660 \mathrm{~cm}^{-1}$ in both of the nanocomposites. INH was intercalated in the anionic form because the proton of the amide nitrogen is highly acidic and its resulting conjugate base is highly stable due to the delocalized negative charge. ${ }^{33}$ However, the FTIR bands would still contain the $\mathrm{N}-\mathrm{H}$ stretching because of the terminal amine group. ${ }^{33,34}$ The presence of the characteristic bands of INH in the FTIR spectra of the nanocomposites supports the XRD evidence of successful intercalation of INH between the interlayer galleries of the $\mathrm{Zn} / \mathrm{Al}-\mathrm{LDHs}$.

B
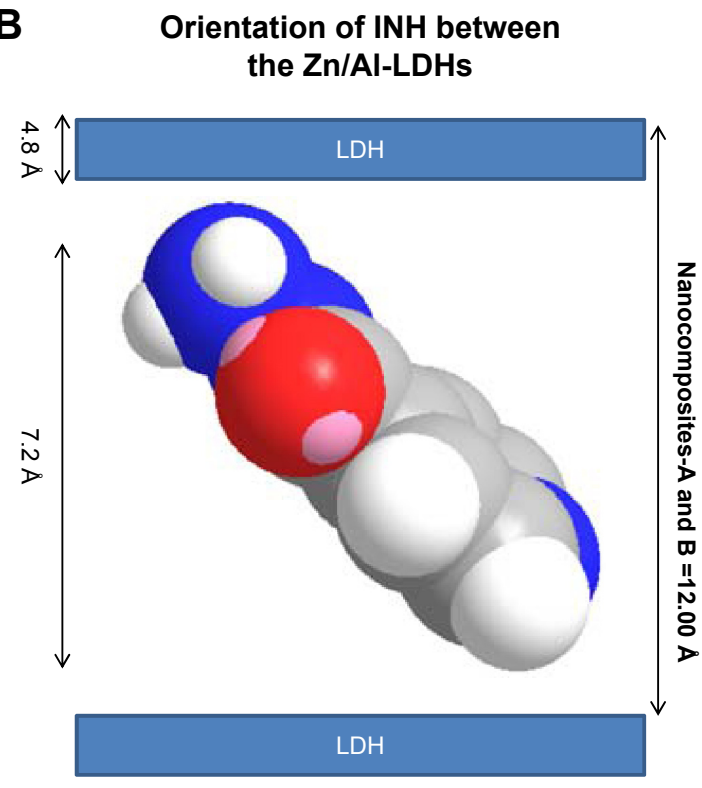

$d=12.0 \AA=7.2-4.8 \AA=4.8 \AA$

Figure 2 (A) Shows the 3-dimensional structure of isoniazid (INH), and (B) the spatial orientation of isoniazid between the inorganic nanolayers. Abbreviation: LDH, layered double hydroxide. 


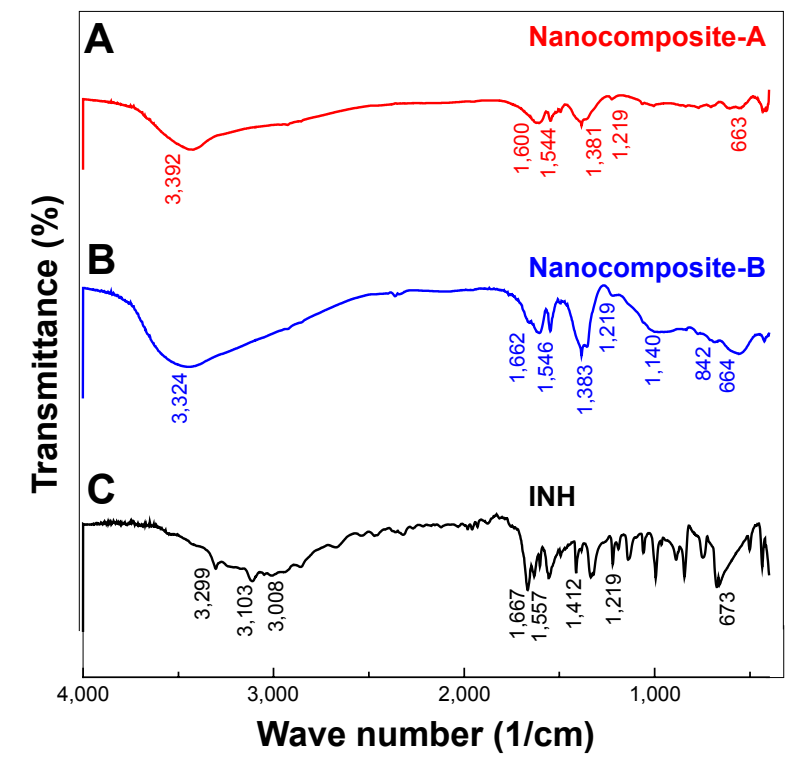

Figure 3 (A-C) FTIR spectra of INH and nanocomposites-A and -B. Abbreviations: FTIR, Fourier transform infrared; INH, isoniazid.

\section{Elemental analysis}

The elemental compositions of INH and nanocomposites-A and $\mathrm{B}$ were determined using carbon, hydrogen, and nitrogen and inductively coupled plasma elemental analysis. In Table 2, the inductively coupled plasma and carbon, hydrogen, and nitrogen results indicated that nanocomposites-A and B contained both organic and inorganic elements. The presence of both inorganic ions (such as zinc and aluminum) and organic elements, such as those present in INH (ie, C, H, and N), in the nanocomposites complement the XRD results to support the successful intercalation of INH. However, the carbonto-nitrogen molar ratios for nanocomposites-A and $\mathrm{B}$ were found to be 3 and 4, respectively, which are higher than the carbon-to-nitrogen ratio of 2 for INH. The higher carbon-tonitrogen molar ratio can be ascribed to the presence of some of $\mathrm{CO}_{3}{ }^{2-}$, which was also observed in the XRD spectra, with a small peak with a d-spacing of $\sim 7.6 \AA$. The percentage of INH loading was determined by the HPLC method described previously with slight modification. ${ }^{29}$ Percentage loading of INH was found to be $12.40 \%$ and $8.33 \%$ in nanocomposites-A and $\mathrm{B}$, respectively, and is given in Table 2 .

The empirical formula for each nanocomposite was found as follows:

$$
\begin{aligned}
& \text { Empirical formula } \\
& \text { for nanocomposite- } \mathrm{A}=\left[\mathrm{Zn}_{0.52} \mathrm{Al}_{0.48}(\mathrm{OH})_{2}\right] \\
& \left(\mathrm{C}_{6} \mathrm{H}_{6} \mathrm{~N}_{3} \mathrm{O}\right)_{0.09}\left(\mathrm{CO}_{3}\right)_{0.195} \cdot 0.6 \mathrm{H}_{2} \mathrm{O} \\
& \text { for nanocomposite- } \mathrm{B}=\left[\mathrm{Zn}_{0.6} \mathrm{Al}_{0.4}(\mathrm{OH})_{2}\right] \\
& \left(\mathrm{C}_{6} \mathrm{H}_{6} \mathrm{~N}_{3} \mathrm{O}\right)_{0.04}\left(\mathrm{CO}_{3}\right)_{0.18} \cdot 0.5 \mathrm{H}_{2} \mathrm{O}
\end{aligned}
$$

\section{Particle size analysis}

Particle size of the $\mathrm{Zn} / \mathrm{Al}-\mathrm{LDHs}$ and the nanocomposites (A and B) was determined with a dynamic light scattering technique using a zeta sizer. The sample was dispersed in deionized water and sample sonicated for 20 minutes and then the sample was analyzed with azeta sizer. The Zn/Al-LDHs alone were found to have a wide distribution of sizes ranging from 50 to $950 \mathrm{~nm}$. According to the cumulative distribution frequency, $\sim 85 \%$ of particles were equal to or less than the $342 \mathrm{~nm}$ (Figure 4A). The particle size of both nanocomposites (A and B) was distributed over a narrow range of $50-300 \mathrm{~nm}$ and $\sim 70 \%$ of the particles were found to have the size equal to or less than $164 \mathrm{~nm}$ as shown in Figure 4B and C, respectively.

\section{Release characteristics of INH}

\begin{tabular}{|c|c|c|c|}
\hline Assignment & $(3 \mathrm{C})$ INH $\left(\mathrm{cm}^{-1}\right)$ & (3B) Nanocomposite-A $\left(\mathrm{cm}^{-1}\right)$ & (3A) Nanocomposite-B $\left(\mathrm{cm}^{-1}\right)$ \\
\hline $\mathrm{N}-\mathrm{H}$ stretching & $3,299^{33}$ & $\begin{array}{l}\text { Overlapped with } \mathrm{OH} \text { of } \mathrm{LDH} \text { and inter } \\
\text { layer water }{ }^{21}\end{array}$ & $\begin{array}{l}\text { Overlapped with } \mathrm{OH} \text { of } \mathrm{LDH} \text { and } \\
\text { interlayer water }\end{array}$ \\
\hline $\begin{array}{l}v(\mathrm{OH}) \text { in the layer; } \mathrm{H}_{2} \mathrm{O} \text { with } \mathrm{OH} \\
\text { stretching }\end{array}$ & - & $3,000-3,450^{21}$ & 3,424 \\
\hline $\mathrm{C}-\mathrm{H}$ asym stretching & 3,104 & $\begin{array}{l}\text { Overlapped with } \mathrm{OH} \text { of } \mathrm{LDH} \text { and interlayer } \\
\text { water }\end{array}$ & $\begin{array}{l}\text { Overlapped with } \mathrm{OH} \text { of } \mathrm{LDH} \text { and } \\
\text { interlayer water }\end{array}$ \\
\hline $\mathrm{C}-\mathrm{H}$ sym stretching & 3,008 & $\begin{array}{l}\text { Overlapped with } \mathrm{OH} \text { of } \mathrm{LDH} \text { and interlayer } \\
\text { water }\end{array}$ & $\begin{array}{l}\text { Overlapped with } \mathrm{OH} \text { of } \mathrm{LDH} \text { and } \\
\text { interlayer water }\end{array}$ \\
\hline $\mathrm{C}=\mathrm{O}$ & 1,660 & 1,600 & 1,608 \\
\hline $\mathrm{N}-\mathrm{H}$ bending & 1,546 & $\mathrm{I}, 544$ & $\mathrm{I}, 546$ \\
\hline $\mathrm{NH}_{2}$ waging & $1,327^{33,34}$ & ।,382 & $\mathrm{I}, 383$ \\
\hline $\mathrm{N}-\mathrm{N}$ & $1,219^{33,34}$ & 1,219 & 1,219 \\
\hline
\end{tabular}

Figure 5A-D shows the release profiles of INH from nanocomposites-A and B in human body-simulated physiological PBS solutions of $\mathrm{pH} 4.8$ simulated to intracellular lysosomal $\mathrm{pH}$ and $\mathrm{pH} 7.4$ simulated to blood $\mathrm{pH}$. Figure $5 \mathrm{~A}$ and $\mathrm{B}$

Table I FTIR vibrational wave numbers of the functional groups

Abbreviations: asym, assymetric; FTIR, Fourier transform infrared; INH, isoniazid; LDH, layered double hydroxide; sym, symmetric. 
Table 2 Elemental composition of INH, nanocomposites-A, and B

\begin{tabular}{llllllll}
\hline Sample & $\mathbf{Z n}(\%$ w/w) & Al (\% w/w) & $\begin{array}{l}\mathbf{Z n}^{2+} / \mathbf{A l}^{3+} \text { molar } \\
\text { elemental ratio }\end{array}$ & $\mathbf{C ~ ( m o l e )}$ & $\mathbf{N}$ (mole) & $\begin{array}{l}\text { Carbon-to-nitrogen } \\
\text { molar ratio }\end{array}$ & $\begin{array}{l}\text { \% drug loading } \\
\text { by HPLC }\end{array}$ \\
\hline INH & - & - & - & 4 & 2 & 2 & - \\
Nanocomposite-A & 58.34 & 22.71 & 1.06 & 1.20 & 0.26 & 4.6 & 12.40 \\
Nanocomposite-B & 33.53 & 5.60 & 2.75 & 1.03 & 0.22 & 4.7 & 8.33 \\
\hline
\end{tabular}

Abbreviations: INH, isoniazid; HPLC, high performance liquid chromatography.

shows the release profiles of INH from nanocomposite-A in PBS solutions at $\mathrm{pH} 4.8$ and 7.4, respectively. The inset figures show the initial release of the INH at the respective $\mathrm{pH}$ values. From nanocomposite-A, initially 55\% of the INH was released at a $\mathrm{pH}$ of 4.8 within 200 minutes (inset of Figure 5A), and the overall release was found to be $91 \%$, which required 5,000 minutes (Figure 5A). At $\mathrm{pH} 7.4$, there was also $\sim 55 \%$ release over 300 minutes initially, which is similar to the profile for $\mathrm{pH} 4.8$; the total release at $\mathrm{pH} 7.4$ was $88 \%$ that took 8,000 minutes. For nanocomposite-B, $60 \%$ INH was initially released within 50 minutes at $\mathrm{pH} 4.8$, and the overall release was determined
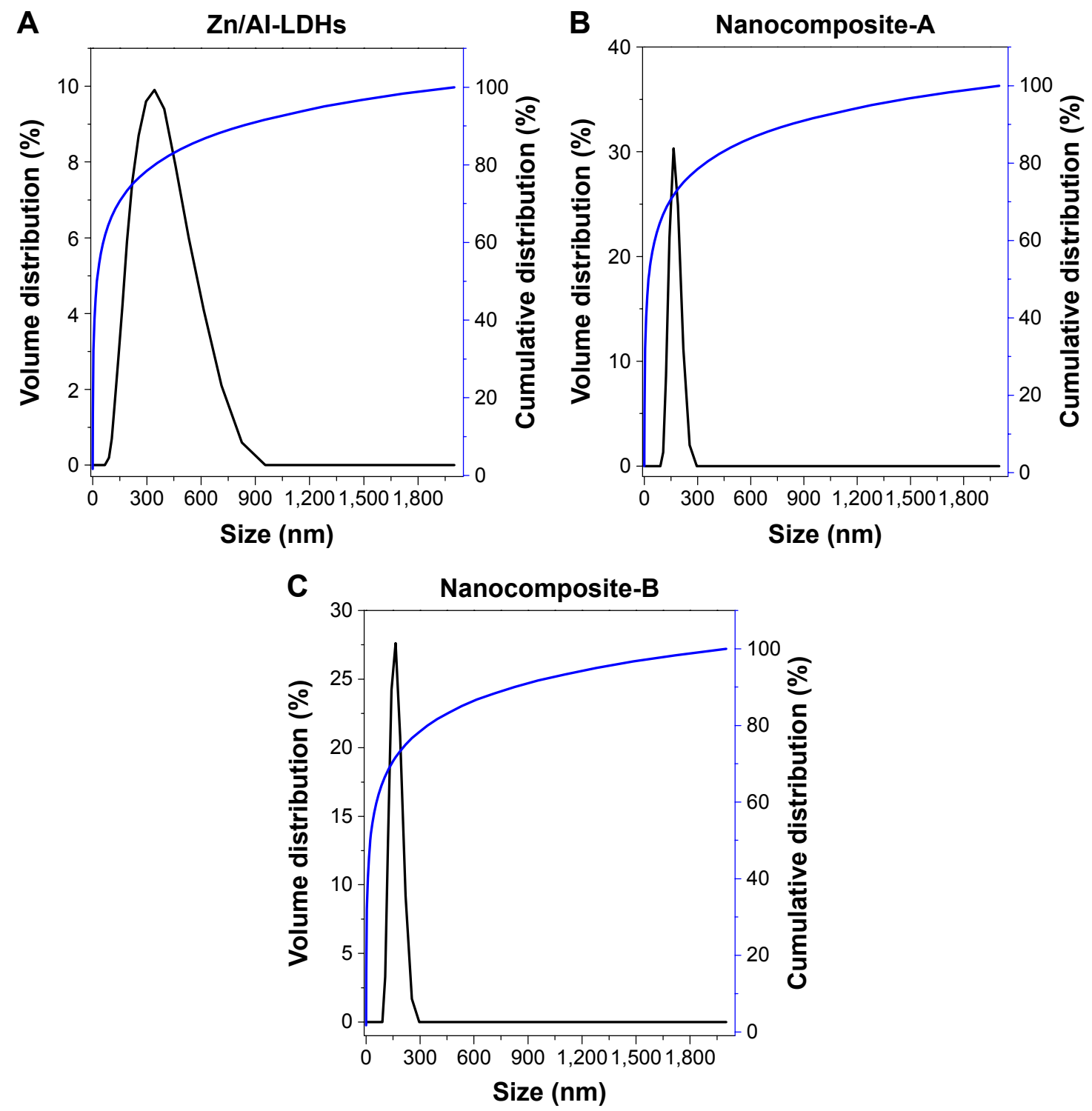

Figure 4 (A-C) Hydrodynamic size of $\mathrm{Zn} / \mathrm{Al}-\mathrm{LDH}$, nanocomposites-A and -B. Abbreviation: LDH, layered double hydroxide. 

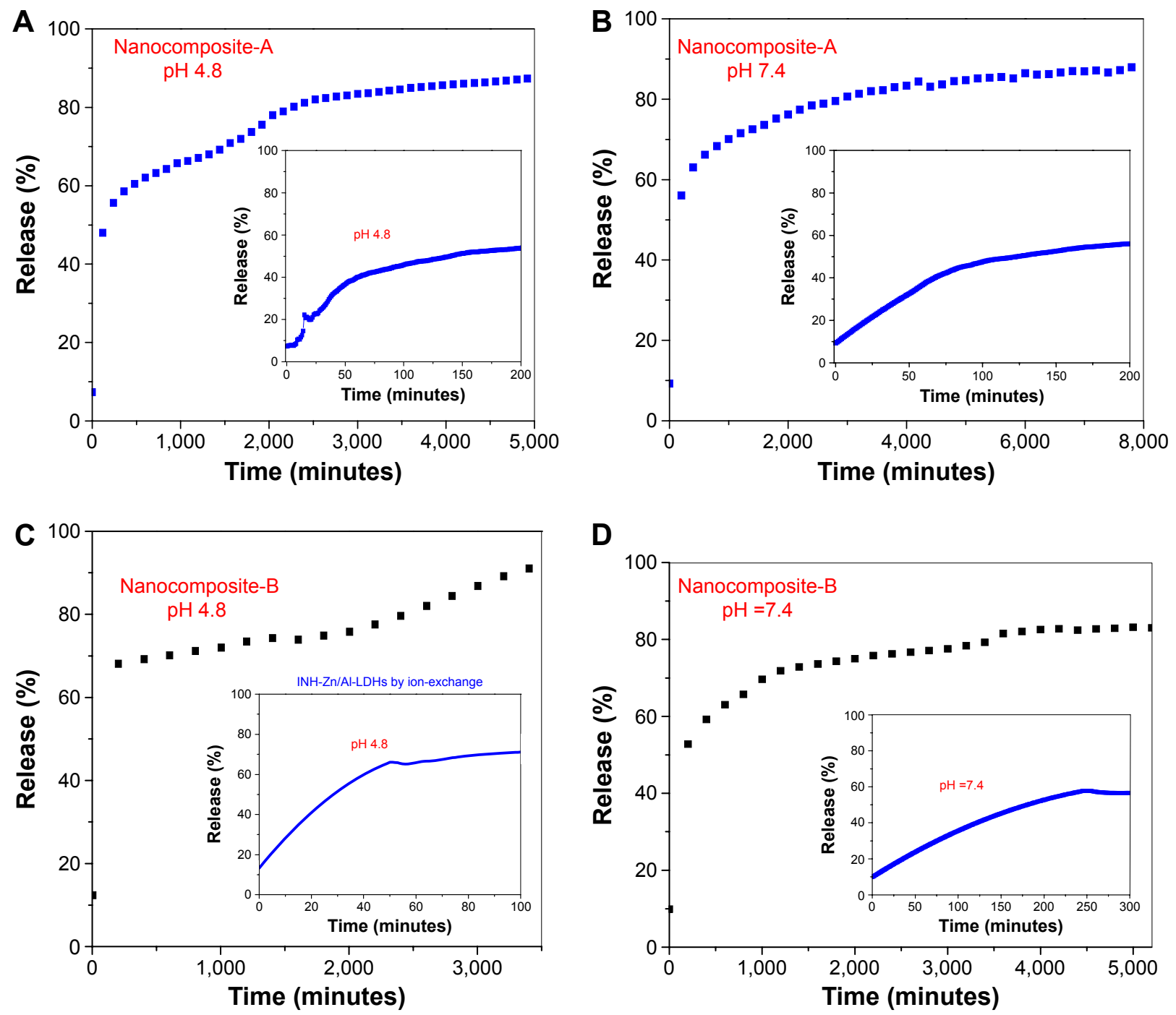

Figure 5 (A-D) Release of isoniazid from the nanocomposites-A and - $\mathrm{B}$ in different human body-simulated physiological buffer solutions with pH values of 7.4 and 4.8 . Abbreviation: LDH, layered double hydroxide.

to be $92 \%$, which took 3,500 minutes (Figure 5C). At pH 7.4, 60\% INH was initially released within 250 minutes from nanocomposite- $\mathrm{B}$, as shown in the inset of Figure 5D. The overall release from nanocomposite-B at $\mathrm{pH} 7.4$ was determined to be $83 \%$, which took $\sim 5,000$ minutes. The overall release is faster for $\mathrm{pH} 4.8$ than for $\mathrm{pH}$ 7.4. The difference in the release profiles, such as a faster release at a lower $\mathrm{pH}$ of 4.8 and a more sustained release at a basic $\mathrm{pH}$ of 7.4 , is due to the difference in the release mechanism. At a lower $\mathrm{pH}$ of 4.8, a slight acidic condition, the drug is released by ion exchange and weathering (degradation) of the LDHs; however at $\mathrm{pH} 7.4$, in alkaline conditions, the release was purely governed by ion exchange. ${ }^{35,36}$ The initial, faster release is relative, and the overall release is shorter at a lower $\mathrm{pH}$ of 4.8 , compared to the release at higher $\mathrm{pH}$ values, due to the weathering phenomenon in acidic $\mathrm{pH}$. The LDHs are basic in nature and therefore are stable at $\mathrm{pH}$ higher than 7; therefore, release in a basic $\mathrm{pH}$ of 7.4 is more sustained as the drug is released by an ion exchange phenomenon and not by weathering of the LDHs - consequently, the release is more sustained at a more basic $\mathrm{pH}$. We analyzed the release graphs and it was noticed that release graphs are more flat indicating that the sustained release was limited during this period.

For the kinetic study of in vitro release, three kinetic models, namely, pseudo-first order, pseudo-second order, and parabolic diffusion described previously, were utilized. . $^{30,31}$ The in vitro release in both of PBS solution of $\mathrm{pH} 4.8$ and $\mathrm{pH}$ 7.4 was found to follow pseudo-second-order pathway. These nanocomposite formulations with the tendency to release the drug relatively faster initially followed by sustained release that would be useful in maintaining the bioavailibility of drug for longer period. 


\section{Release kinetics of INH from nanocomposites-A and $B$}

The kinetic process of the drug release can be determined by applying different models, for example, the pseudo-first-order model, the pseudo-second-order model, or parabolic diffusion. The kinetic equations for these models are as follows. The kinetic equation for the pseudo-first-order model in linear form is: ${ }^{36}$

$$
\ln \left(q_{\mathrm{e}}-q_{\mathrm{t}}\right)=\ln q_{\mathrm{e}}-k_{1} t
$$

where $q_{\mathrm{e}}$ represents the amount released at equilibrium, and $q_{\mathrm{t}}$ represents the amount released at any time $(t)$. The constant $k_{1}$ is the equilibrium constant and can be determined by the slope of the plot of $\left(q_{\mathrm{e}}-q_{\mathrm{t}}\right)$ against $t$. The kinetic equation for the second-order model is represented in the linear form: ${ }^{30}$

$$
t / q_{\mathrm{t}}=1 / k_{2} q_{\mathrm{e}}^{2}+t / q_{\mathrm{e}}
$$

and the parabolic diffusion kinetic equation may be represented as: $:^{31}$

$$
\left(1-M_{\mathrm{t}} / M_{0}\right) / t=k t^{-0.5}+b
$$

where $M_{0}$ and $M_{\mathrm{t}}$ are the drug contents that remained in the nanocomposites at release time 0 and at any time $(t)$, respectively. We used the earlier equations for the three kinetic models, and only a pseudo-second-order model was fitted linearly for the release from nanocomposites-A and $\mathrm{B}$ at both $\mathrm{pH} 4.8$ and 7.4. The correlation coefficients $\left(R^{2}\right)$ were determined to be higher than for the pseudo-first-order and parabolic diffusion kinetic models. Table 3 shows the values of the correlation coefficients for different models and the rate constant for second-order kinetics. Figure 6 represents plots of the pseudo-second order equation fits for the release of INH from nanocomposites-A and B at pH 4.8 and 7.4 .

\section{Anti-TB and antimicrobial activities}

The highly efficient and accurate although expensive system of BBL BACTEC MGIT 960 described previously ${ }^{32,37}$ was utilized for the MICs of the as-synthesized INH-Zn/ Al-LDH nanocomposites-A and B against $M$. tuberculosis as shown in Figure 7, and were found to be $7.4 \mu \mathrm{g} / \mathrm{mL}$ compared to that of $2.3 \pm 0.35 \mu \mathrm{g} / \mathrm{mL}$ for the free drug (INH). Based on the INH loading (determined by HPLC), the actual concentrations of INH (effective INH concentration) in $7.4 \mu \mathrm{g}$ are $\sim 0.91$ and $0.62 \mu \mathrm{g}$ in nanocomposites- $\mathrm{A}$ and $\mathrm{B}$, respectively. The actual MIC values based on the effective INH concentration of the MIC for the nanocomposites-A and B are 0.91 and $0.62 \mu \mathrm{g} / \mathrm{mL}$, respectively. The therapeutic efficacy of INH intercalated into LDHs is approximately three times higher than its free INH. The improved efficacy can be attributed to the nanoscale size of the INH-LDH structure and the sustained release of INH from the nanocomposites.

The results of the antimicrobial testing using growth kinetics showed that the nanocomposites have antibacterial activity against Gram-positive bacteria, Gram-negative bacteria, and C. albicans, as is shown in Figure 8A and B. The additional antibacterial activity of the nanocomposites compared to the free INH, which lacks antimicrobial activity, is advantageous in the treatment of polymicrobial infections that may be associated with TB infections.

\section{Cytotoxicity effects of nanocomposites on human normal lung cells (MRC-5) and mouse fibroblast cells (3T3)}

The MTT assay is a colorimetric method to investigate the cell viability after exposure to various synthetic bioactive compounds and nanocomposites. Hence, in this biological experiment, we used an MTT assay to assess the cytotoxicity of the pure drug (INH) and nanocomposites-A and B utilizing a previously developed method. ${ }^{22,38}$ The cytotoxicity values of the pure drug

Table 3 Correlation coefficient $\left(R^{2}\right)$ and rate constants $(k)$ obtained by fitting the data of the release kinetics of isoniazid from nanocomposites-A and - $\mathrm{B}$ into PBS solutions at $\mathrm{pH} 4.8$ and 7.4

\begin{tabular}{lllllll}
\hline Samples & pH & Release (\%) & $\boldsymbol{R}^{2}$ & & & $\begin{array}{l}\text { Pseudo-second } \\
\text { order }\end{array}$ \\
\hline & & & Pseudo-first order & Pseudo-second order & Parabolic diffusion model & $\begin{array}{l}\text { Rate constant } \boldsymbol{k} \\
\text { (mg/min) }\end{array}$ \\
\hline Nanocomposite-A & 4.8 & 96 & 0.9187 & 0.9962 & 0.7648 & $2.77 \times 10^{-5}$ \\
Nanocomposite-A & 7.4 & 92 & 0.8771 & 0.9962 & 0.7054 & $2.68 \times 10^{-5}$ \\
Nanocomposite-B & 4.8 & 95 & 0.9017 & 0.9982 & 0.6226 & $9.23 \times 10^{-5}$ \\
Nanocomposite-B & 7.4 & 80 & 0.9032 & 0.9988 & 0.6713 & $6.98 \times 10^{-5}$ \\
\hline
\end{tabular}

Abbreviation: PBS, phosphate-buffered saline. 

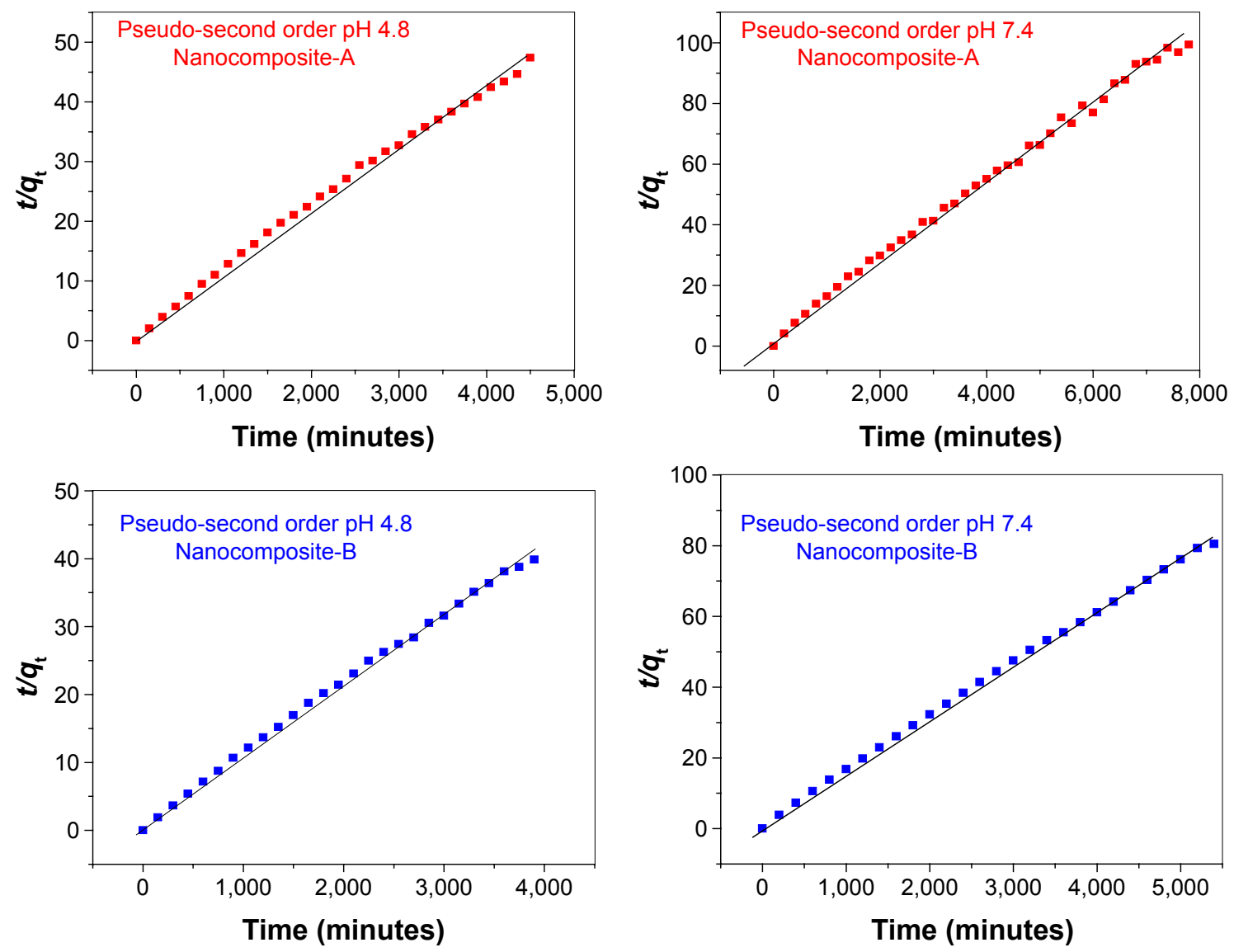

Figure 6 Pseudo-second-order kinetics of the isoniazid release from nanocomposites-A and -B in various phosphate-buffered saline solutions at $\mathrm{pH} 4.8$ and 7.4 .

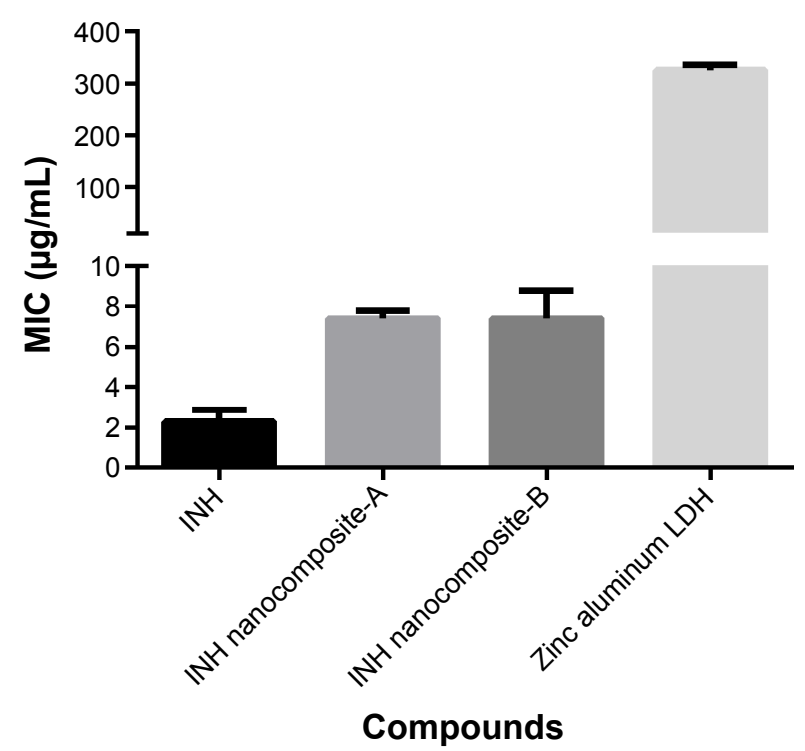

Figure 7 Minimum inhibitory concentrations (MICs) $(\mu \mathrm{g} / \mathrm{mL})$ of INH nanocomposites.

Notes: The MIC of INH nanocomposites-A and -B as compared to INH free drug against Mycobacterium tuberculosis were determined using the MGIT using the BACTEC MGIT 960 growth supplement for DST and measured by the MGIT 960 instrument (Becton Dickinson Diagnostic Systems, Sparks, MD, USA).

Abbreviations: INH, isoniazid; $\mathrm{LDH}$, layered double hydroxide; MGIT, mycobacteria growth indicator tube; DST, drug susceptibility testing.
INH and its $\mathrm{Zn} / \mathrm{AL}-\mathrm{LDHs}$ (nanocomposites-A and $\mathrm{B}$ ) on human normal lung MRC-5 and 3T3 mouse fibroblast cells are shown in Figure 9A-C. Various concentrations (ie, from 0.781 to $50 \mu \mathrm{g} / \mathrm{mL}$ ) of nanocomposites-A and B did not show any reduction in the cell viability during 24,48 , and 72 hours of inhibition. The empty carrier Zn/Al-LDH has been reported to possess no cytotoxicity on both of the above-mentioned cell lines. ${ }^{23}$ In comparison to the nanocomposites (A and B), empty $\mathrm{Zn} / \mathrm{Al}-\mathrm{LDHs}$ and the naked INH show significant toxic effects on human normal lung MRC-5 and 3T3 mouse fibroblast cells in a dose- and timedependent manner. If we have a look at the (Figure 9C) highest concentration, $50 \mu \mathrm{g} / \mathrm{mL}$ at 72 hours, the free drug shows $80 \%$ cell death and $20 \%$ cell viability; however, both of the nanocomposites showed the vice versa effect (ie, $80 \%$ cell viability and only $20 \%$ cell death). So, comparatively, the $80 \%$ cell viability is three times higher compared to $20 \%$. Based on this preliminary investigation, we suggest that nanocomposite formulations are three times more biocompatible than the free drug INH at a higher concentration, that is, $50 \mu \mathrm{g} / \mathrm{mL}$ at 72 hours. 
A

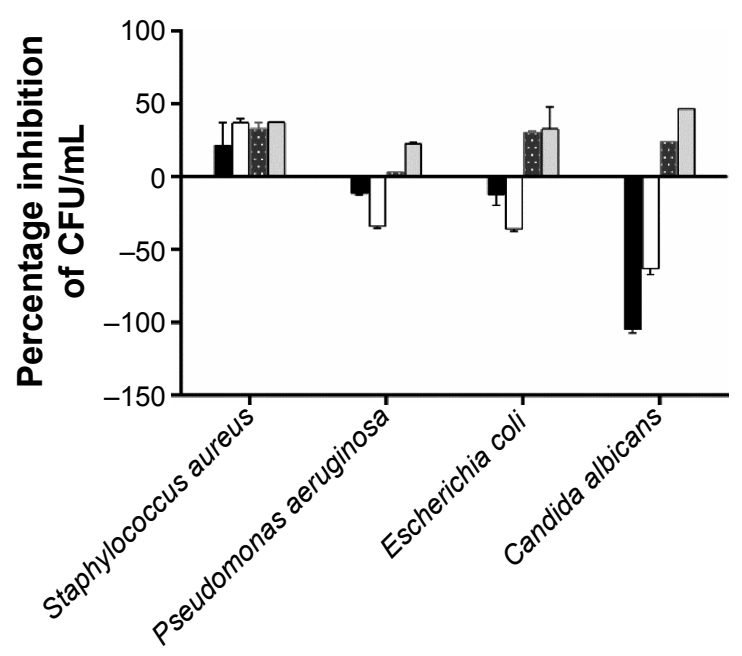

Microorganisms

$\square$ INH $1 \mathrm{mg} \square \mathrm{Zn} \mathrm{Al-LDH} 1 \mathrm{mg}$

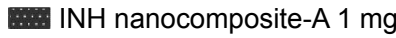

$\square$ INH nanocomposite-B $1 \mathrm{mg}$
B

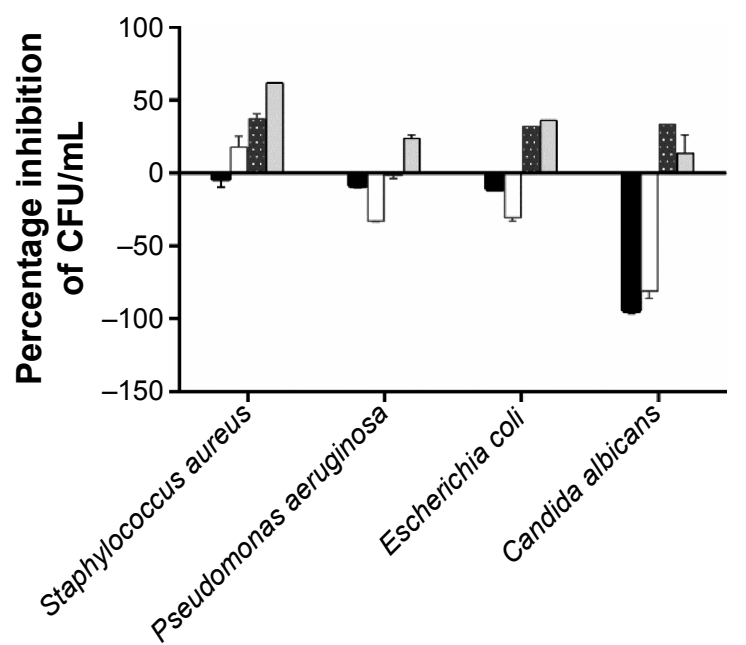

Microorganisms

INH 2 mg $\square$ Zn Al-LDH 2 mg

INH nanocomposite-A $2 \mathrm{mg}$

INH nanocomposite-B $2 \mathrm{mg}$

Figure 8 Microbial growth kinetics of INH and INH nanocomposites (A) and (B).

Note: The effects of INH, INH nanocomposites, and the components of the nanocomposites on different microorganisms using the percentage inhibition in the number of CFUs.

Abbreviations: INH, isoniazid; LDH, layered double hydroxide; CFUs, colony forming units.

A

Mouse fibroblast cells 3T3

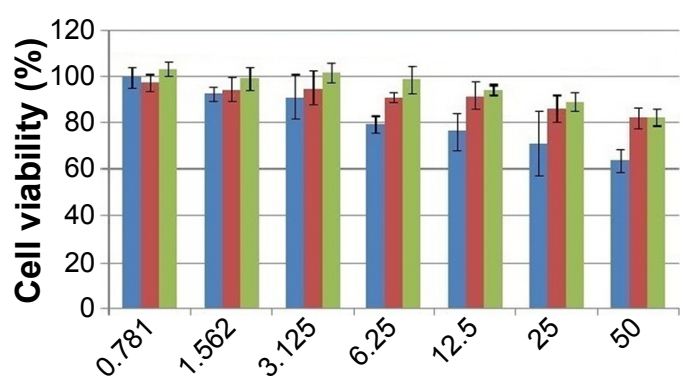

Concentration $(\mu \mathrm{g} / \mathrm{mL})$

B

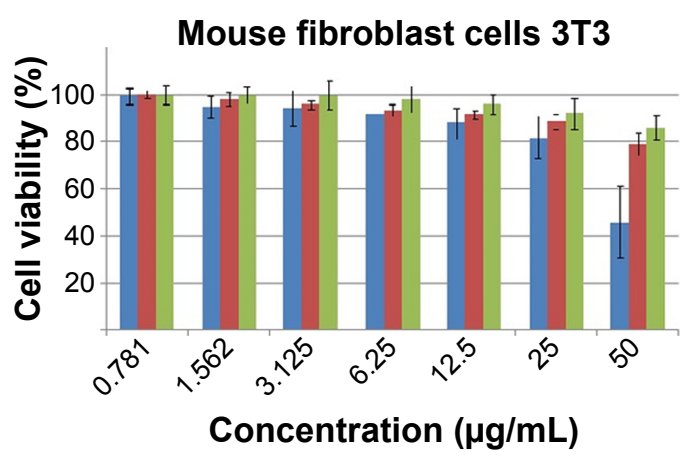

24 hours

Human normal lung cells MRC-5

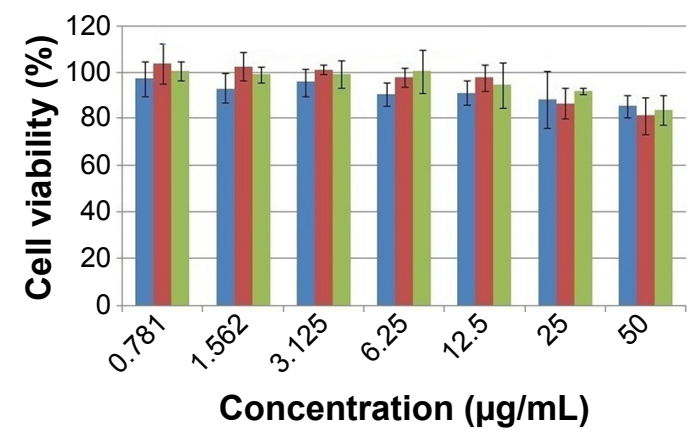

48 hours

Human normal lung cells MRC-5

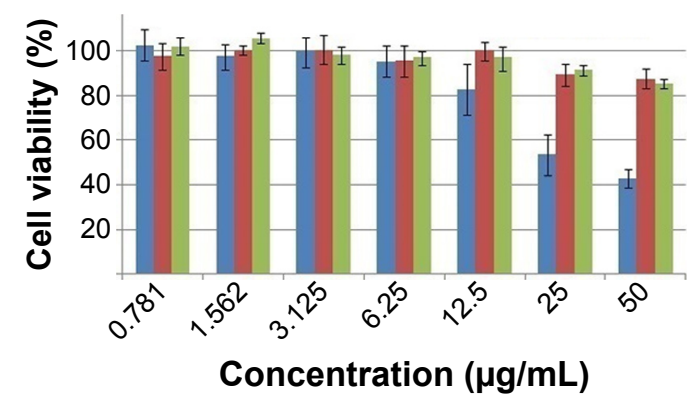

Figure 9 (Continued) 
C

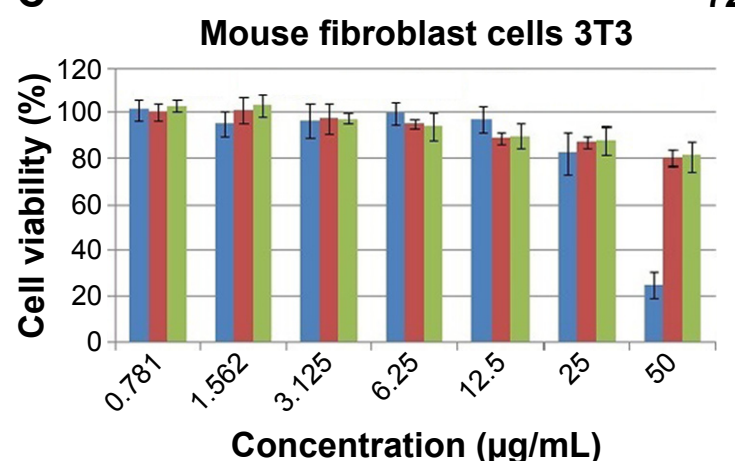

72 hours

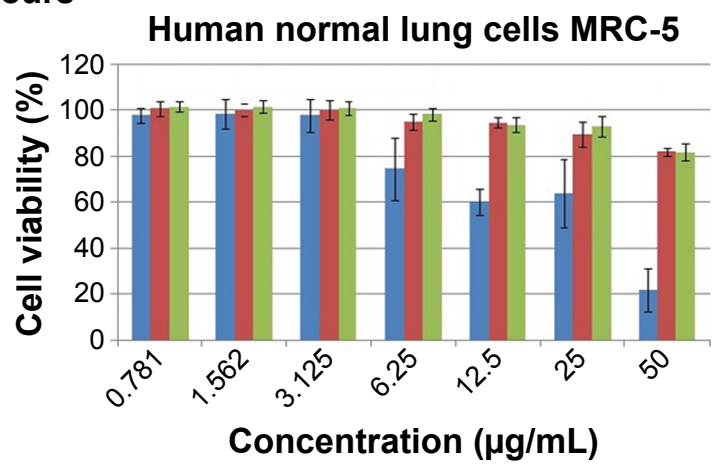

$\square$ INH $\square$ Nanocomposite-A $\square$ Nanocomposite-B

Figure 9 Cell viability (MTT assay) of 3 T3 mouse fibroblast cells and human lung fibroblast MRC-5 cells against various gradient concentrations exposed for (A) 24, (B) 48, and $(\mathbf{C}) 72$ hours.

Note: The data presented are mean \pm SD of triplicate samples.

Abbreviations: 3T3, mouse fibroblast cells; MRC-5, human lung cells; SD, standard deviation; INH, isoniazid.

\section{Conclusion}

We have developed anti-TB nanodelivery formulations by intercalating the anti-TB drug INH into $\mathrm{Zn} / \mathrm{Al}-\mathrm{LDHs}$ with nanoscaled size of the particle, that is, $164 \mathrm{~nm}(70 \%)$. The INH intercalated into $\mathrm{Zn} / \mathrm{AL}$-LDHs was determined to be threefold more effective at killing mycobacteria compared to the INH in its free form. The developed formulations were determined to be threefold more biocompatible with human normal lung cells and 3T3 fibroblast mouse skin cells. The release of the INH from the formulation was sustained in a simulated human PBS solution and follows pseudo-secondorder kinetics. The improved efficacy can minimize the TB treatment duration, and the high biocompatibility can decrease the adverse side effects. The short treatment duration and decreased side effects would ultimately improve patients' compliance to the chemotherapy for TB. Further in vivo investigation and experimental studies using animal models will provide potential data on the effects of these nanocomposites on the inflammatory responses due to TB infection and their clinical usefulness and applications in the treatment of TB.

\section{Acknowledgments}

The authors would like to thank the Malaysian Higher Education Commission (MOHE), the Ministry of Science, Technology and Innovation of Malaysia (MOSTI), Dr MH El Sayed, for his in part help in the analysis of TB results, and Northeastern University of Boston, MA, USA. The authors would like to thank University Putra Malaysia for financial support through Vot\#9443100 for Dr Mohd Zobir Hussein and the Northeastern University, Boston, MA, USA, for funding the antituberculosis experiments for Dr Thomas J Webster and Dr Mohamed Ezzat El Zowalaty.

\section{Disclosure}

The authors report no conflicts of interest in this work.

\section{References}

1. Unaids WHOGTPA. Policy statement on preventive therapy against tuberculosis in people living with HIV. Presented at: World Health Organization Global Tuberculosis Programme and UNAIDS; February 18-20; 1998; Geneva.

2. Sumartojo E. When tuberculosis treatment fails. A social behavioral account of patient adherence. Am Rev Respir Dis. 1993;147(5):1311-1320.

3. Cuneo WD, Snider DE Jr. Enhancing patient compliance with tuberculosis therapy. Clin Chest Med. 1989;10(3):375-380.

4. WHO. Guidelines for the Programmatic Management of Drug-Resistant Tuberculosis. Geneva: World Health Organization; 2011:44.

5. Hasan S, Al Ali H, Al-Qubaisi M, et al. Controlled-release formulation of antihistamine based on cetirizine zinc-layered hydroxide nanocomposites and its effect on histamine release from basophilic leukemia (RBL-2H3) cells. Int J Nanomedicine. 2012;7:3351-3363.

6. WHO. Global Tuberculosis Report. Geneva: World Health Organization; 2014.

7. Sharma SK, Mohan A. Extrapulmonary tuberculosis. Indian J Med Res. 2004;120(4):316-353.

8. Agarwal S, Gupta M, Choudhury B. Solvent free biocatalytic synthesis of isoniazid from isonicotinamide using whole cell of Bacillus smithii strain IITR6b2. J Mol Catal B: Enzym. 2013;97:67-73.

9. Campos-Franco J, Gonzalez-Quintela A, Alende-Sixto MR. Isoniazidinduced hyperacute liver failure in a young patient receiving carbamazepine. Eur J Intern Med. 2004;15(6):396-397.

10. Vidrio H, Medina M, Fernández G, Lorenzana-Jiménez M, Campos AE. Enhancement of hydralazine hypotension by low doses of isoniazid: Possible role of semicarbazide-sensitive amine oxidase inhibition. Gen Pharmacol. 2000;35(4):195-204.

11. Tafazoli S, Mashregi M, O’brien PJ. Role of hydrazine in isoniazidinduced hepatotoxicity in a hepatocyte inflammation model. Toxicol Appl Pharmacol. 2008;229(1):94-101.

12. Van Hest R, Baars H, Kik S, et al. Hepatotoxicity of rifampin-pyrazinamide and isoniazid preventive therapy and tuberculosis treatment. Clin Infect Dis. 2004;39(4):488-496.

13. Gupta A, Kaul A, Tsolaki AG, Kishore U, Bhakta S. Mycobacterium tuberculosis: immune evasion, latency and reactivation. Immunobiology. 2012;217(3):363-374.

14. Saifullah B, Hussein MZ, Hussein Al Ali SH. Controlled-release approaches towards the chemotherapy of tuberculosis. Int J Nanomedicine. 2012;7:5451-5463. 
15. Clemens DL, Lee BY, Xue M, et al. Targeted intracellular delivery of antituberculosis drugs to Mycobacterium tuberculosis-infected macrophages via functionalized mesoporous silica nanoparticles. Antimicrob Agents Chemother. 2012;56(5):2535-2545.

16. Bermudez LE, Goodman J. Mycobacterium tuberculosis invades and replicates within type II alveolar cells. Infect Immun. 1996;64(4): 1400-1406.

17. Flynn JL, Chan J. Immune evasion by Mycobacterium tuberculosis: living with the enemy. Curr Opin Immunol. 2003;15(4):450-455.

18. Chen H, Wang L, Yeh J, et al. Reducing non-specific binding and uptake of nanoparticles and improving cell targeting with an antifouling PEO-b-PgammaMPS copolymer coating. Biomaterials. 2010;31(20): 5397-5407.

19. He Q, Zhang Z, Gao F, Li Y, Shi J. In vivo biodistribution and urinary excretion of mesoporous silica nanoparticles: effects of particle size and PEGylation. Small. 2011;7(2):271-280.

20. Anisimova YV, Gelperina SI, Peloquin CA, Heifets LB. Nanoparticles as antituberculosis drugs carriers: Effect on activity against mycobacterium tuberculosis in human monocyte-derived macrophages. J Nanopart Res. 2000:2(2):165-171.

21. Saifullah B, Hussein MZ, Hussein-Al-Ali SH, Arulselvan P, Fakurazi S. Sustained release formulation of an anti-tuberculosis drug based on para-amino salicylic acid-zinc layered hydroxide nanocomposite. Chem Cent J. 2013;7(1):72.

22. Saifullah B, Hussein MZ, Hussein-Al-Ali SH, Arulselvan P, Fakurazi S. Antituberculosis nanodelivery system with controlled-release properties based on para-amino salicylate-zinc aluminum-layered double-hydroxide nanocomposites. Drug Des Devel Ther. 2013;7:1365-1375.

23. Del Hoyo C. Layered double hydroxides and human health: An overview. Appl Clay Sci. 2007;36(1-3):103-121.

24. Cavani F, Trifirò F, Vaccari A. Hydrotalcite-type anionic clays: Preparation, properties and applications. Catal Today. 1991;11(2):173-301.

25. Saifullah B, Hussein MZ. Inorganic nanolayers: structure, preparation, and biomedical applications. IJNM. 2015;10:24

26. Rives V, Del Arco M, Martín C. Layered double hydroxides as drug carriers and for controlled release of non-steroidal antiinflammatory drugs (NSAIDs): a review. J Control Release. 2013;169(1-2):28-39.
27. Rives V, Del Arco M, Martín C. Intercalation of drugs in layered double hydroxides and their controlled release: A review. Appl Clay Sci. 2014;88-89:239-269.

28. Newman SP, Jones W. Synthesis, characterization and applications of layered double hydroxides containing organic guests. New J Chem. 1998;22(2):105-115.

29. Dhal SK, Sharma R. Development and Validation of RP-HPLC Method for Simultaneous Determination of Pyridoxine Hydrochloride, Isoniazid, Pyrazinamide and Rifampicin in pharmaceutical Formulation. Warszawa: Instytut Chemii Fizycznej, POLOGNE. 54; 2009.

30. Kong X, Shi S, Han J, Zhu F, Wei M, Duan X. Preparation of Glycy1-Tyrosine intercalated layered double hydroxide film and its in vitro release behavior. Chem Eng J. 2010;157(2-3):598-604.

31. Ho YS, Ofomaja AE. Pseudo-second-order model for lead ion sorption from aqueous solutions onto palm kernel fiber. J Hazard Mater. 2006;129(1-3):137-142.

32. Walters SB, Hanna BA. Testing of susceptibility of Mycobacterium tuberculosis to isoniazid and rifampin by mycobacterium growth indicator tube method. J Clin Microbiol. 1996;34(6):1565-1567.

33. Husain A. Amide derivatives of sulfonamides and isoniazid: synthesis and biological evaluation. Acta Pol Pharm. 2009;66(5):513-521.

34. Gunasekaran SS, Seshadri E, Kumaresan S. FTIR, FT Raman spectra and molecular structural confirmation of isoniazid. IJPAP. 2009; 47(1):5.

35. Rojas R, Palena MC, Jimenez-Kairuz AF, Manzo RH, Giacomelli CE. Modeling drug release from a layered double hydroxide-ibuprofen complex. Appl Clay Sci. 2012;62-63:15-20.

36. Parello ML, Rojas R, Giacomelli CE. Dissolution kinetics and mechanism of $\mathrm{Mg}-\mathrm{Al}$ layered double hydroxides: A simple approach to describe drug release in acid media. J Colloid Interface Sci. 2010;351(1):134-139.

37. Palaci M, Ueki SY, Sato DN, Da Silva Telles MA, Curcio M, Silva EA. Evaluation of mycobacteria growth indicator tube for recovery and drug susceptibility testing of Mycobacterium tuberculosis isolates from respiratory specimens. J Clin Microbiol. 1996;34(3):762-764.

38. Wen CC, Chen HM, Chen SS, et al. Specific microtubule-depolymerizing agents augment efficacy of dendritic cell-based cancer vaccines. J Biomed Sci. 2011;18:44.
International Journal of Nanomedicine

\section{Publish your work in this journal}

The International Journal of Nanomedicine is an international, peerreviewed journal focusing on the application of nanotechnology in diagnostics, therapeutics, and drug delivery systems throughout the biomedical field. This journal is indexed on PubMed Central, MedLine, CAS, SciSearch $®$, Current Contents $\AA /$ Clinical Medicine,

\section{Dovepress}

Journal Citation Reports/Science Edition, EMBase, Scopus and the Elsevier Bibliographic databases. The manuscript management system is completely online and includes a very quick and fair peer-review system, which is all easy to use. Visit http://www.dovepress.com/ testimonials.php to read real quotes from published authors. 